\title{
The Principal's Leadership Strategy in Improving Quality: A Study at Aron State Elementary School Pidie Aceh Indonesia
}

\author{
Nurhayati \\ Department of Educational Administration \\ Universitas Syiah Kuala, Indonesia \\ profcut@yahoo.com
}

\author{
Cut Zahri Harun \\ Department of Educational Administration \\ Universitas Syiah Kuala, Indonesia \\ profcut@yahoo.com
}

\author{
Bahrun \\ Department of Educational Administration \\ Universitas Syiah Kuala, Indonesia \\ profcut@yahoo.com
}

\begin{abstract}
The purpose of this research was to determine the leadership style, motivation, school organizational culture and obstacles faced by the principal in improving the quality of Aron State Elementary School in Pidie Regency. This research used a descriptive method with a qualitative approach. The research subjects were: school principals, vice principals, KKG chairmen, teachers, supervisors, and school committees. Data collection techniques were conducted by observation, interview, and documentation. Data analysis is done by data reduction, data display, verification and conclusion. The results showed that: (1) The leadership style applied is more likely to be democratic leadership styles, such as: not imposing a will, looking at subordinates as partners, building cooperation as a work team, giving trust to subordinates, accepting criticism, and giving freedom to creativity to subordinates; (2) Motivation is given through coaching and training programs, creating a comfortable school environment and environment, giving reward and punishment; (3) The school organizational culture that is applied is the midnight prayer activities, reading books, $5 \mathrm{~S}$ programs, PHBI activities, monday ceremonies, reading prayers when starting and after learning, memorizing juz 30, giving examples, slogans and symbols in the environment school; and (4) The obstacles faced are the low motivation of teachers in improving their competence, there are still teachers who are less disciplined in carrying out their duties, as well as the limited facilities and infrastructure that support the learning process.
\end{abstract}

Keywords: strategy, principal leadership, and school quality

\section{INTRODUCTION}

Principal leadership is an ability carried out by the principal in influencing, guiding, coordinating and mobilizing school personnel in order to achieve educational and teaching goals. The quality of education in schools is also influenced by the leadership of principals in improving the performance of teachers or subordinates (Ulfa \& Waluyo, 2016; Kalsum, 2016; Verawati, 2016).

In carrying out its leadership function, the school principal must carry out school management and guidance through administrative, management and leadership activities that are highly dependent on his ability. The results of research conducted by Ekosiswoyo (2016) the leadership factor is needed in supporting the process of improving the quality of education, because the style or behavioral characteristics shown by the leader will be able to influence and move individuals or groups in the organization they lead.

The principal has a typical leadership leadership style in interacting with his subordinates. The principal's leadership style is the behavior pattern (words and actions) of the principal who is perceived by others. The role of the principal's leadership style is an important factor in directing schools to improve the quality of education. This is consistent with the results of Sari's (2013) study which concluded that there was a contribution of the principal's leadership style and achievement motivation to the quality of education.
This shows that there is a significant contribution of the principal's leadership style to teacher performance (Djailani \& Usman, 2015; Ali, 2015).

The school principal needs to motivate the teacher as an effort to move the teacher in developing creativity and developing all of his abilities. As in the results of the research, Rahmi (2018) concluded that teacher motivation contributes to student learning outcomes. To improve teacher performance, there needs to be an increase in the leadership of school principals to provide work motivation, as well as good job satisfaction, which will improve teacher performance (Wardhani \& Soetomo, 2017). If you have high motivation and competence and are supported by good leadership, it will improve performance.

Every activity carried out at school must be a school culture and lead to quality. As in the results of Umam's research, et al. (2017) the implementation of a quality culture that includes active, innovative, creative, effective and fun learning. The impact of implementing a quality culture that includes the creation of enjoyable learning, the creation of interesting learning conditions and the encouragement of learning, increased character values, and increased learning achievement. Leadership and organizational culture are significantly related to performance.

Many factors can influence a person's performance, as school leaders must be able to apply appropriate leadership styles, create a good school 
climate and culture, make decisions or policies that are right for the school, and provide motivation that can cause teachers to be moved to carry out their duties effectively so their performance will be better. This is consistent with the results of research conducted by Setiyati (2014) there is a positive and significant influence between the principal's leadership, work motivation, school culture on teacher performance.

In the context of education, quality refers to the educational process and the results of education. The school principal needs to pay attention to internal and external factors of the school to transform the school environment to achieve school quality (Triatna, 2017). Quality schools are schools that are able to provide educational services or services that match or exceed the expectations and satisfaction of their customers.

One factor that determines quality is the leadership of the school principal. As a result of research conducted by Sulastri, et al. (2017) there is a positive and significant influence of the principal's leadership on school quality. Therefore, it is necessary to control quality by conducting quality assurance that meets specified standards and expectations.

The results of interviews and initial observations by the principal and several teachers of Aron State Elementary School in Pidie District showed that the teacher lacked discipline in carrying out his duties, the communication that occurred between the teacher and the principal was one-way communication from the principal, so the principal seemed to rule a lot without being accompanied opinions from subordinates. The principal rarely gives motivation, appreciation or praise to the teacher so that the teacher is less than optimal in carrying out his duties. Rarely discussions between school principals and school personnel also cause less principals' transparency and school administration, financing and decision making are not objective.

The above problems show that the school climate such as interpersonal relationships, a conducive learning environment, a pleasant environment, and the school spirit have not shown a positive atmosphere that affects school quality. School quality must be used as a school culture in providing services to school residents which includes the environment, atmosphere, nature, and school climate productively capable of achieving educational success based on the spirit and values adopted by the school.

Based on the above problems, the research objective is to find out: (1) the leadership style applied by the principal; (2) the motivation given by the principal; (3) the school culture applied; and (4) the obstacles faced by the principal in improving the quality of Aron State Elementary School in Pidie Regency.

\section{METHODS}

This research is a qualitative research. According to Patilima (2013) that: "Qualitative research as a process of inquiry to understand social problems based on the creation of holistic images formed by words, reporting the views of informants in detail and arranged in a scientific setting. This study seeks to explore information in depth about the leadership of principals in improving quality so that the various uniqueness contained in the individuals, groups, communities, and/or Aron State Elementary School organizations in Pidie Regency are comprehensive, detailed, in-depth, and scientifically accountable.

Data collection is done by interviewing, observing and studying documents. Interviews were conducted with school supervisors, principals, KKG chairmen, teachers, and school committees in accordance with the focus of the problem. Observations are made to check the correctness of the data provided through confirmation and document studies are complementary to the use of observation and interview methods. Then the researcher collected a number of data from the interview between subjects compared with each other, then analyzed and adjusted to documentary data, and finally concluded. Data analysis is done by: data reduction, data presentation and conclusion drawing.

\section{RESULTS AND DISCUSSION}

\section{Principal Leadership Style}

Based on the results of the study, it can be seen that the leadership style of Aron Elementary School principals in improving quality is more likely to be a democratic leadership style. This can be seen from treating the teacher as a friend, not imposing the will, looking at subordinates as partners, building cooperation as a work team, giving trust to subordinates, receiving criticism for the progress of teachers and schools, giving freedom to creativity to subordinates, building passion with creating a conducive environment.

The principal's leadership style appears in an effort to influence school staff to carry out tasks in order to achieve educational goals. The principal's leadership certainly runs management in accordance with the organizational climate. Situational leadership style emphasizes that leadership success is determined by leader behavior and organizational situational factors, such as type of work, organizational environment, and characteristics of individuals involved in the organization (Senny, 2018). This needs to be done because of the leadership of the principal, the school climate and the teacher's competency and significant and simultaneous influence on the quality of education in schools (Susanto \& Mattalatta, 2018).

\section{Motivation Given by the Principal}

The results showed that the motivation given by the principal in improving the quality of education at Aron Elementary School in Pidie Regency was through coaching and training programs for education staff and teachers, creating a comfortable school environment and atmosphere, giving rewards and punishment.

The motivation given by the principal is one of the factors that determine the success of the principal in leading his school. According to Torang (2016) the motivation process includes a cycle 
abbreviated as AIDA, namely attention, interesting, desire (aroused), and action. Motivating teachers can consist of giving awards that can foster initiative, creative abilities, and a healthy spirit of competition.

The principal must have the right strategy to motivate the education staff in carrying out various tasks and functions (Suandi, et al, 2018). This motivation can be cultivated through the regulation of the physical environment, work atmosphere, discipline, encouragement, effective appreciation and the provision of various learning resources through the development of learning resource centers. The results of the research by Zein \& Hadijah (2018) the positive impact of organizational commitment and work motivation on teacher performance which in turn would have a positive impact on school quality.

\section{School Organizational Culture in Improving School Quality}

The results showed that the school organizational culture applied by the school principal in improving the quality of education in Aron Elementary School in Pidie Regency was in the form of: Dhuhr prayer activities in congregation, reading books, Ramadhan pesantren activities, $5 \mathrm{~S}$ programs, PHBI activities, Monday activities, habitual reading prayer when starting and after learning, asmaul husna and memorizing juz 30, scouting extra curricular activities.

All of these programs are integrated in daily activities in the form of: giving examples/examples, slogans and symbols in the school environment and integrating through learning activities. School culture is characterized by the existence of regular ways of acting from all school members that can be observed such as certain ritual events, language used or certain symbols that reflect the values espoused by school members.

As Kompri (2015) argues that: school culture is a view of life that is recognized jointly by a community group, which includes ways of thinking, behavior, attitudes, values that are reflected, both in physical and abstract forms. The role played by school principals in building school culture greatly determines the quality of schools (Sunaengsih, 2017; Heryanto, 2017). The role played by the school leader is in the form of continuous coaching in terms of modeling, teaching, and strengthening character that is good for all school residents (teachers, students, and employees).

The implementation of quality culture has a positive impact on improving the quality of education. Umam's et al (2017) research results: (1) the implementation of a quality culture that includes active, innovative, creative, effective and fun learning; (2) supporting factors and inhibiting the implementation of quality culture; and (3) the impact of implementing a quality culture that includes the creation of pleasant learning; creating interesting learning conditions and encouraging learning; increasing character values; and increased learning achievement.

\section{Constraints Faced in Improving School Quality}

Based on the results of the study showed that the obstacles faced by the principal in improving the quality of Aron Public Elementary School in Pidie Regency were that teachers were less disciplined with the agreed rules, there was still a lack of motivation for teachers to gain insight or read books, journals and other references, both fields general as well as with regard to the material that will be taught to students, there are still teachers who lack discipline in carrying out their duties, and there are still limited facilities and infrastructure that support the learning process.

Schools will advance if they are led by visionary principals, have managerial competence, high dedication, and personality integrity in quality improvement. Thus, an educational institution is highly dependent on the effectiveness of leadership oriented towards the achievement of graduate quality and the best service for customers (education consumers).

One of the efforts of the principal in improving the quality of education in his school is to stay in a place where he is assigned, to socialize to the community around the school how important education is for school-age children, improve the qualifications of teachers and educators, improve the competence of students and graduates, improve schools through various activities, including scouting extracurricular activities and completing school infrastructure in stages (Liskayani \& Sulastri, 2018).

\section{CONCLUSION}

The leadership style of the Aron Elementary School principal in improving quality is more likely to be a democratic leadership style. This can be seen from treating the teacher as a friend, not imposing the will, looking at subordinates as partners, building cooperation as a work team, giving trust to subordinates, receiving criticism for the progress of teachers and schools, giving freedom to creativity to subordinates, building passion with creating a conducive environment.

The motivation given by the school principal in improving the quality of schools is through coaching and training programs for education staff and teachers, creating a comfortable school environment and environment, providing reward and punishment.

School organizational culture applied by principals in improving school quality is in the form of: Dhuhr prayer activities in congregation, reading books, Ramadhan pesantren activities, 5S programs, PHBI activities, monday ceremonies, reading prayers when starting and after learning, asmaul husna and memorizing juz 30, scouting extracurricular activities. All of these programs are integrated in daily activities in the form of: giving examples, slogans and symbols in the school environment and integrating through learning activities.

The obstacles faced by the principal in improving quality are the teacher's lack of motivation in improving his competence, there are still teachers who lack discipline in carrying out their duties, and the limited facilities and infrastructure that support the learning process. 


\section{REFERENCES}

[1] Ali, S. N. M., Harun, C. Z., \& Djailani, A. R. 2015. Principal Leadership Style in Improving Teacher Performance in Lambaro Angan Public Elementary School. Journal of Educational Administration, 3(2), 116-127.

[2] Djailani, A. R., \& Usman, N. 2015. Principal Leadership Style in Improving Teacher Performance at SDN 7 Muara Dua Lhoksuemawe. Journal of Educational Administration, 3(2), 38-48.

[3] Ekosiswoyo, R. 2016. Principal Leadership Effective Keys to Achieving Educational Quality. Journal of Educational Science, 14(2), 76-82.

[4] Heryanto, A. 2017. Effect of Visionary Leadership on School Principals and School Culture on Primary Quality Management. Journal of Educational Administration, 21(2), 88-95.

[5] Kalsum, U. 2016. Principal Leadership Description and Performance of Science Teachers of Sederajat Middle School in Kepenuh Hulu Subdistrict. Scientific Journal of Students of FKIP Biology Study Program, 2(1), 1-6.

[6] Kompri. 2015. Education Management 3. Bandung: Alfabeta.

[7] Liskayani, L., \& Sulastri, S. 2018. Principal Strategies in Rural Areas to Improve the Quality of Education and Character of School Residents. JMKSP (Journal of Management, Leadership and Educational Supervision), 3(1), 77-89.

[8] Patilima, H. 2013. Qualitative Research Methods. Bandung: Alfabeta.

[9] Rahmi, A. 2018. Contribution of Principal Supervision and Teacher Motivation to Student Learning Outcomes at MTsN Padang Parak Laweh. Macromac-Ind, 1(3), 10-20.

[10] Sari, D. P. 2013. Contribution of Principal Leadership Style and Motivation of Achievement of Teachers Towards Quality of Education in Rama Group 2 UPT DISDIKPORA Kembang District, Jepara Regency. Jurnal Manajemen Pendidikan, 2, 102-103.

[11] Senny, M. H., Wijayaningsih, L., \& Kurniawan, M. 2018. Application of Transformational Leadership Style in PAUD Management in Sidorejo District Salatiga. Scholaria: Journal of Education and Culture, 8(2), 197-209.

[12] Setiyati, S. 2014. Effect of Principal Leadership, Work Motivation, and School Culture on Teacher Performance. Journal of Technology and Vocational Education, 22(2), 200-206.

[13] Suandi, I. W., Lasmawan, W., \& Natajaya, N. 2018. Relationship between Situational Leadership, Work Motivation and Work Climate with Teacher Performance. Journal of Research and Development in Science and Humanities, 1(2), 42-50.

[14] Sulastri, S., Nurkolis, N., \& Rasiman, R. 2017. Effect of Principal Leadership and Work Motivation on Primary School Quality in Jepara Regency. Journal of Education Management (JMP), 5(3), 346-361.

[15] Sunaengsih, C. 2017. The Influence of Transformational Leadership of Principals and School Culture on the Quality of Schools in Public and Private Middle Schools in Bandung City. Journal of Educational Administration, 14(2), 1-10.

[16] Susanto, B., \& Mattalatta, M. 2018. Effect of Principal Leadership, School Climate and Teacher Competence on Quality of Education in MTS Jeneponto Regency. YUME: Journal of Management, 1(2), 23-39.
[17] Torang, S. 2016. Organization \& Management (Behavior, Structure, Culture \& Organizational Change). Bandung: Alfabeta.

[18] Triatna, C. 2017. Transformational Leadership of Principals in Realizing School Quality. Journal of Educational Administration, 3(1), 1-14.

[19] Ulfa, D., \& Waluyo, E. 2016. Relationship Between Visionary Leadership of Principals and Teachers' Performance of Early Childhood Education Institutions in Purworejo Sub District of Purworejo Regency, Central Java. BELIA: Early Childhood Education Papers, 5(2), 70-73.

[20] Umam, K., Sudharto, S., \& Miyono, N. 2017. Implementation of Quality Culture at the Integrated Islamic Primary School (SDIT) Al Islam Kudus Regency. Journal of Educational Management (JMP), 6(2), 203-215.

[21] Umam, K., Sudharto, S., \& Miyono, N. 2017. Implementation of Quality Culture at the Integrated Islamic Primary School (SDIT) Al Islam Kudus Regency. Journal of Educational Management (JMP), 6 (2), 203-215.

[22] Verawati, R. 2016. The Influence of Leadership, Work Motivation and Work Commitment to the Performance of Public Madrasah Aliyah (MAN) Teachers in Lubuk Alung. Journal of Economic and Economic Education, 4(2), 296-307.

[23] Wardhani, E. W., \& Soetomo, W. E. 2017. Effect of Principal Leadership and Work Motivation on Teacher Performance with Teacher Job Satisfaction as Mediation Variables in SMA Negeri 11 Semarang. Journal of Vision Management, 2(2), 139-155.

[24] Zein, A. K. A., \& Hadijah, H. S. 2018. Effect of Organizational Commitment and Work Motivation on Teacher Performance in Pasundan 1 Vocational High School Cimahi. Journal of Office Management Education, 2(1), 62-68. 